\title{
AVALIAÇÃO DO POTENCIAL PARA EDUCAÇÃO AMBIENTAL DO PASSEIO PÚBLICO DE CURITIBA
}

\author{
Cláudia Regina Bosa ${ }^{1}$, Fabiane Féxina² \\ ${ }^{1}$ Professora e orientadora do Curso de Especialização em Conservação da Natureza e Educação Ambiental da PUC/PR, \\ Zoológico Municipal de Curitiba (crbosa@hotmail.com) \\ ${ }^{2}$ Especialista em Conservação da Natureza e Educação Ambiental, PUC-PR (ffexina@yahoo.com.br)
}

\section{RESUMO}

A busca pelo contato com a natureza cresce diariamente, principalmente por aqueles que vivem em grandes cidades. Frente à grave crise ambiental que afeta a todos, a relação entre turismo e educação ambiental surge como uma possibilidade de mudar o comportamento das pessoas e trazer soluções para amenizar os prejuízos causados pelo ser humano ao meio ambiente. 0 objetivo do presente trabalho foi analisar o potencial do Parque Passeio Público de Curitiba, Paraná, como um local disseminador de conceitos ligados à educação ambiental. Esse espaço possui em seu plantel vários animais em cativeiro e alguns espaços arborizados. O presente trabalho foi realizado através de observações do local e aplicação de 100 questionários. Verificouse que os visitantes ainda possuem muitos hábitos desfavoráveis à conservação da natureza, mas demonstraram interesse e motivação para receber informações que possam mudar suas atitudes e valores pró-ambiente. Dos entrevistados, $96 \%$ acreditam que podem melhorar seu comportamento em relação ao meio ambiente se conhecerem mais sobre o assunto. Curiosidades sobre os hábitos dos animais, lazer, ervas medicinas, lixo, maquetes e exposições são alguns dos assuntos de maior interesse entre os visitantes. Por outro lado, o Passeio Público apresenta algumas deficiências quando se trata de dar ao visitante o acesso ao conhecimento mínimo sobre sua fauna. A partir dos resultados, pode-se concluir que práticas de educação ambiental no Passeio Público, podem gerar mudanças nas atitudes e motivações ambientalistas de seus visitantes, mas para isso, é preciso maior investimento e estudos sobre a melhor metodologia para aplicação da educação ambiental neste ambiente.

Palavras-chave: Áreas verdes urbanas; turismo; Informação ambiental.

\section{ABSTRACT}

The search for contact with nature is increasingly growing, mainly by those who live in large cities. Faced with serious environmental crisis that affects everyone, the relationship between Tourism and Environmental Education emerges as a possibility to change people's behavior and provide solutions to mitigate the damage caused by humans to the environment. The objective of this study was to analyze the potential of Parque Passeio Público, Curitiba, Paraná, as a site disseminating concepts related to Environmental Education. This space has in his breeding stock several captive animals and some wooded areas. This work was conducted through observations of the site and questionnaires to visitors. It was found that many visitors still have bad habits towards nature conservation, but have shown interest in and motivation to receive information 
Monografias Ambientais

that can change their attitudes and values pro-environment. Of the respondents, $96 \%$ believe they can improve their behavior towards the environment if they learn more about it. Curiosities about animal habits, recreation, medicinal herbs, garbage, scale models and exhibitions are some of the topics of most interest among visitors. On the other hand, the Passeio Público fails to provide visitors with information about its fauna. We can conclude from the results that the practice of Environmental Education at Passeio Público can cause change in environmental attitudes and motivation of its visitors; however, there must be more investment and research on the best methodology for implementation of Environmental Education in the environment.

Keywords: Urban green areas; Tourism; Environmental information.

\section{INTRODUÇÃO}

Nos últimos tempos, a crise ambiental refletida através da degradação das condições de vida, especialmente nas grandes cidades, demonstra a urgência de reflexão em relação às formas e aos desafios de despertar as pessoas quanto à questão ambiental (JACOBI, 2003).

Há atualmente, nos diferentes setores sociais, uma forte tendência em reconhecer o processo educativo como uma possibilidade de provocar mudanças e alterar este quadro de degradação (BERTE, 2004).

Uma das maneiras de mudar as atitudes do ser humano em relação ao meio em que vive, de modo que as gerações futuras possam desfrutar dos recursos naturais tanto quanto a geração atual, surge através da educação ambiental. Entende-se por educação ambiental (artigo Art. 1ㅇ da lei $n^{\circ} 9.795$ de 27 de abril de 1999):

Processo em que se busca despertar a preocupação individual e coletiva para a questão ambiental, garantindo o acesso à informação em linguagem adequada, contribuindo para o desenvolvimento de uma consciência crítica e estimulando o enfrentamento das questões ambientais e sociais. Desenvolve-se num contexto de complexidade, procurando trabalhar não apenas a mudança cultural, mas também a transformação social, assumindo a crise ambiental como uma questão ética e política (BRASIL, 1999).

Castanheira (2004, p.88) ainda diz que "a educação ambiental é transformadora e que essa nova visão e postura do ser humano com o seu meio será eficaz na medida em que sua abrangência vai atingindo a totalidade dos grupos sociais".

O turismo, setor que movimenta milhões de pessoas de todas as classes, atuando a nível local, nacional e global, tem atualmente como um de seus principais produtos, a natureza. Todos os espaços de beleza considerável vem sendo invadidos por uma multidão individualista que desconsidera os riscos que sua presença causa no frágil meio ambiente (RUSCHMANN, 2000).

Para Jacobi (2003, p.192):

A postura de dependência e de desresponsabilização da população decorre principalmente da desinformação, da falta de consciência ambiental e de um déficit de práticas comunitárias baseadas na participação e no envolvimento dos cidadãos, que proponham uma nova cultura de direitos baseada na motivação e na co-participação da gestão ambiental. 
Sendo assim, é inegável o compromisso da atividade turística com a conservação da biodiversidade, e já que a 'busca' pela natureza preservada é uma das maiores motivações de viagens e passeios, a educação para o turismo envolve necessariamente educação ambiental (RUSCHMANN, 2000).

Segundo Castanheira (2004), formas sustentáveis de turismo podem contribuir para a conservação da biodiversidade dentro e fora das áreas protegidas, como também melhorar a qualidade de vida das pessoas.

Deste modo, as áreas verdes urbanas aparecem como uma grande oportunidade de combinar turismo e educação ambiental.

O turismo, enquanto uma atividade que auxilia o processo de aprendizagem justifica sua utilização na medida em que promove o desenvolvimento social, crítico e educativo (BONFIM, 2010). Castanheira (2004, p.89) ainda afirma que:

A educação ambiental tem um caráter permanente, pois a evolução do senso crítico e a compreensão da complexidade dos aspectos que envolvem as questões ambientais dão-se de um modo crescente e contínuo, não se justificando sua interrupção. Despertada a consciência, se ganha um aliado para a melhoria das condições de vida no planeta.

A importância de tal estudo justifica-se pelo fato de que as áreas verdes urbanas são pouco aproveitadas no sentido de educar, sensibilizar e conscientizar os cidadãos sobre seu papel na sociedade. A área focada nesta pesquisa é o Passeio Público de Curitiba, Paraná, que apresenta grande relevância para a conservação da biodiversidade, pois conta com a presença de um número representativo de fauna e flora nativa e exótica.

Cerca de $10 \%$ da população mundial visita anualmente os zoológicos, convertendo-os num grande palco para educar e sensibilizar a humanidade sobre a necessidade de conservar a biodiversidade. $E$, se a isso somarmos a possibilidade de contribuir diretamente com a conservação, esses locais tem justificada plenamente sua razão de ser (MINISTÉRIO, 2004). Além disso, a cidade de Curitiba, conhecida pela preocupação com a sustentabilidade, torna tal estudo viável, a fim de complementar outras ações "sustentáveis" já criadas pelo poder público, podendo ainda ganhar maior notoriedade através da preocupação em demonstrar, em ambiente aberto, o que muitas vezes só se aprende em sala de aula. Desta forma, vale ressaltar que, nesta pesquisa, a contribuição do turismo na educação e da educação no turismo é defendida partindo-se do pressuposto de que haja um turismo planejado e sustentável, levando em conta o caráter preservacionista do local de estudo. Planejamento é fundamental e indispensável para um desenvolvimento turístico equilibrado e em harmonia com os recursos físicos, culturais e sociais das regiões receptoras (RUSCHMANN, 2000).

O presente trabalho teve como objetivo avaliar o potencial e verificar a percepção dos visitantes do Passeio Público de Curitiba quanto à utilização deste como instrumento para práticas em educação ambiental.

\section{MATERIAL E MÉTODOS}

Foi realizado estudo exploratório sobre o tema, através de pesquisa bibliográfica (livros, revistas, internet).

Para Martins e Lintz (2000), a fase exploratória é fundamental para definir o escopo do objeto de estudo, estabelecendo os contatos iniciais para o trabalho de campo. 
Monografias Ambientais

No período de maio/2011 a junho/2011, foram feitas visitas ao Passeio Público, para conhecer a infraestrutura do parque, além de verificar o que é oferecido dentro da temática da educação ambiental aos visitantes.

Marconi (2009, p. 69), entende que "a pesquisa de campo permite que se estabeleça um modelo teórico inicial de referência, da mesma forma que auxilia na determinação das variáveis e na elaboração do plano geral da pesquisa". Durante o mês de agosto/2011, foram aplicados questionários aos visitantes para identificar a percepção destes sobre o parque e o nível de interesse sobre a temática ambiental. Já que o Passeio Público não possui um controle no fluxo de visitantes, foi feita uma amostragem não probabilística, do tipo acidental, com um número total de 100 pessoas, sendo selecionados por estarem no local e segundo a disponibilidade destes em responder o questionário. De acordo com Braga (2007), os elementos deste tipo de amostra são escolhidos por estarem no local de estudo, e cabe ao pesquisador definir o tamanho da amostra, uma vez que não é possível o emprego de cálculos estatísticos.

A análise dos dados referentes ao questionário de opinião pública foi quantitativa, representada por gráficos, para uma melhor visualização e um melhor entendimento de seus resultados. Já a análise dos dados referentes às visitas ao Passeio Público foi qualitativa.

O trabalho foi submetido e aprovado pelo Comitê de Ética da PUCPR, sob o protocolo número 6153, versão 002.

\subsection{LOCAL DE ESTUDO - PASSEIO PÚBLICO DE CURITIBA}

O Passeio Público é o parque mais antigo e o mais central de Curitiba, inaugurado em 1886. Com cerca de 70 mil m² $^{2}$, possui várias atrações (FIG. 1) e está localizado na confluência das ruas Carlos Cavalcante, Presidente Faria, João Gualberto e Luís Leão (NOGUEIRA, 2010). 


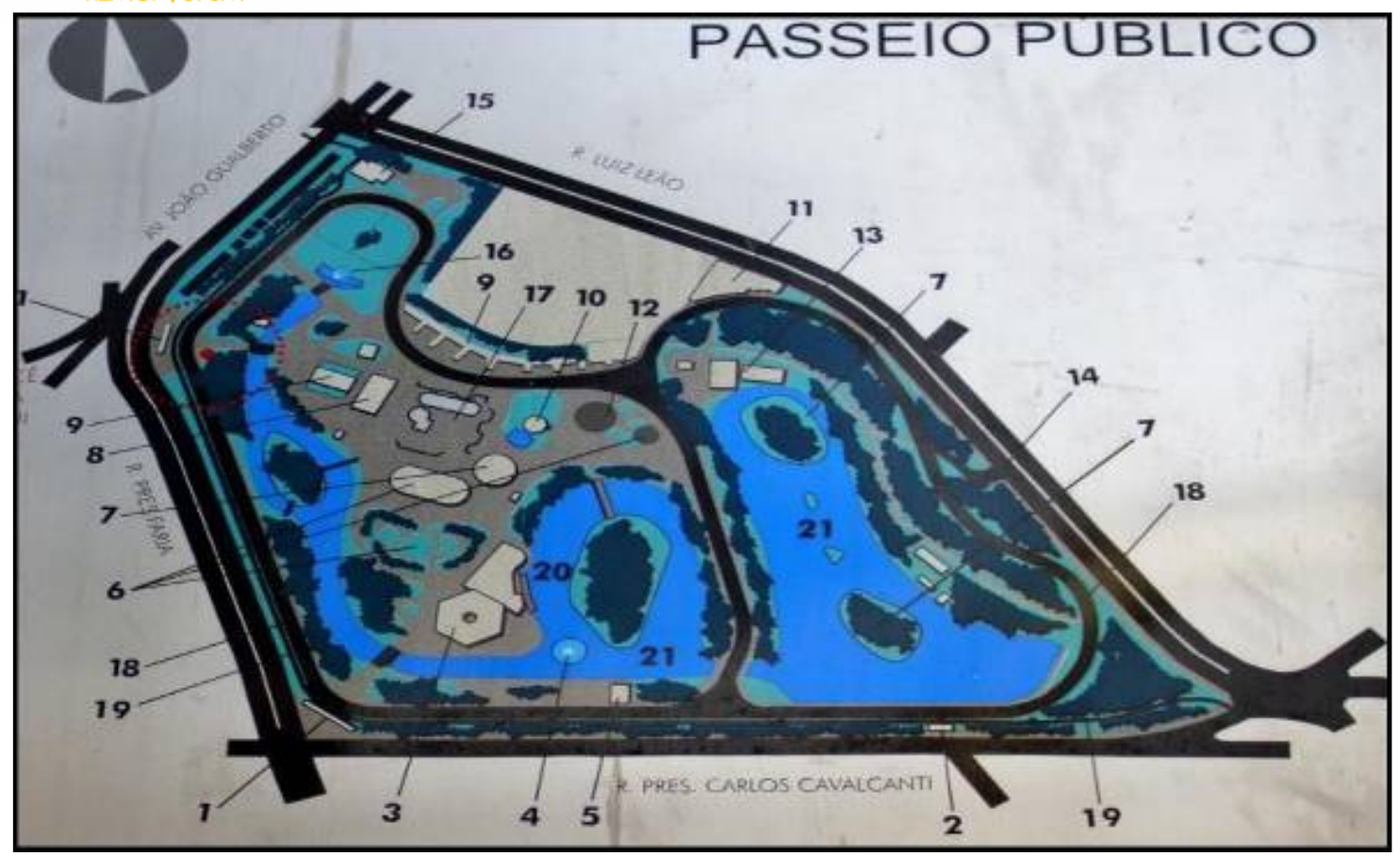

Figura 1. Croqui do Passeio Público Fonte: Secretaria Municipal do Meio Ambiente, 2010 (modificado pela autora).

Legenda:

\begin{tabular}{l|l|l|}
\hline 1. Portal principal & 8. Terrário/sanitários & 15. Bicicletário/lanchonete \\
2. Portal secundário & 9. Viveiro das aves & 16. Fonte \\
3. Restaurante & 10. Aquário & 17. Playground \\
4. Chafariz & 11. Administração & 18. Rua interna/caminhada \\
5. Sede da Policia Militar & 12. Pista de patinação & 19. Ciclovia \\
6. Recinto das aves & 13. Sede de manutenção & 20. Deck pedalinhos \\
7. Recinto dos macacos & 14. Acesso de serviços & 21. Lago \\
\hline
\end{tabular}

Foi criado por Alfredo D’Escragnolle Taunay, quando presidente da Província do Paraná, na tentativa de amenizar o problema da área, que era um grande banhado. A partir de sua inauguração, o local se tornou o ponto de encontro mais tradicional de Curitiba. (SECRETARIA MUNICIPAL DO MEIO AMBIENTE DE CURITIBA, 2010).

Foi por um tempo, durante o século 19, o primeiro Jardim Botânico de Curitiba. Foi também o primeiro zoológico de Curitiba até 1982, quando a maioria dos animais foi transferida para o zoológico no Parque Iguaçu. Entre as curiosidades, está o fato de, nos tempos antigos, serem usados lampiões alimentados por azeite de peixe para iluminar o local (NOGUEIRA, 2010).

O Rio Belém, que cortava a região, transformou-se num lago para o lazer dos curitibanos. Algumas obras foram sendo feitas ao longo do tempo, para corrigir problemas de engenharia e em 1910, foi construído em uma das entradas do parque, um portão inspirado nas linhas arquitetônicas do portão do Cemitério de Cães de Asnières, em Paris. A réplica curitibana (FIG. 2), idealizada pelo arquiteto alemão (radicado curitibano) Frederico Kirchgässner, foi tombada pelo Patrimônio Histórico e Artístico do Paraná, em 1974 (NOGUEIRA, 2010). 


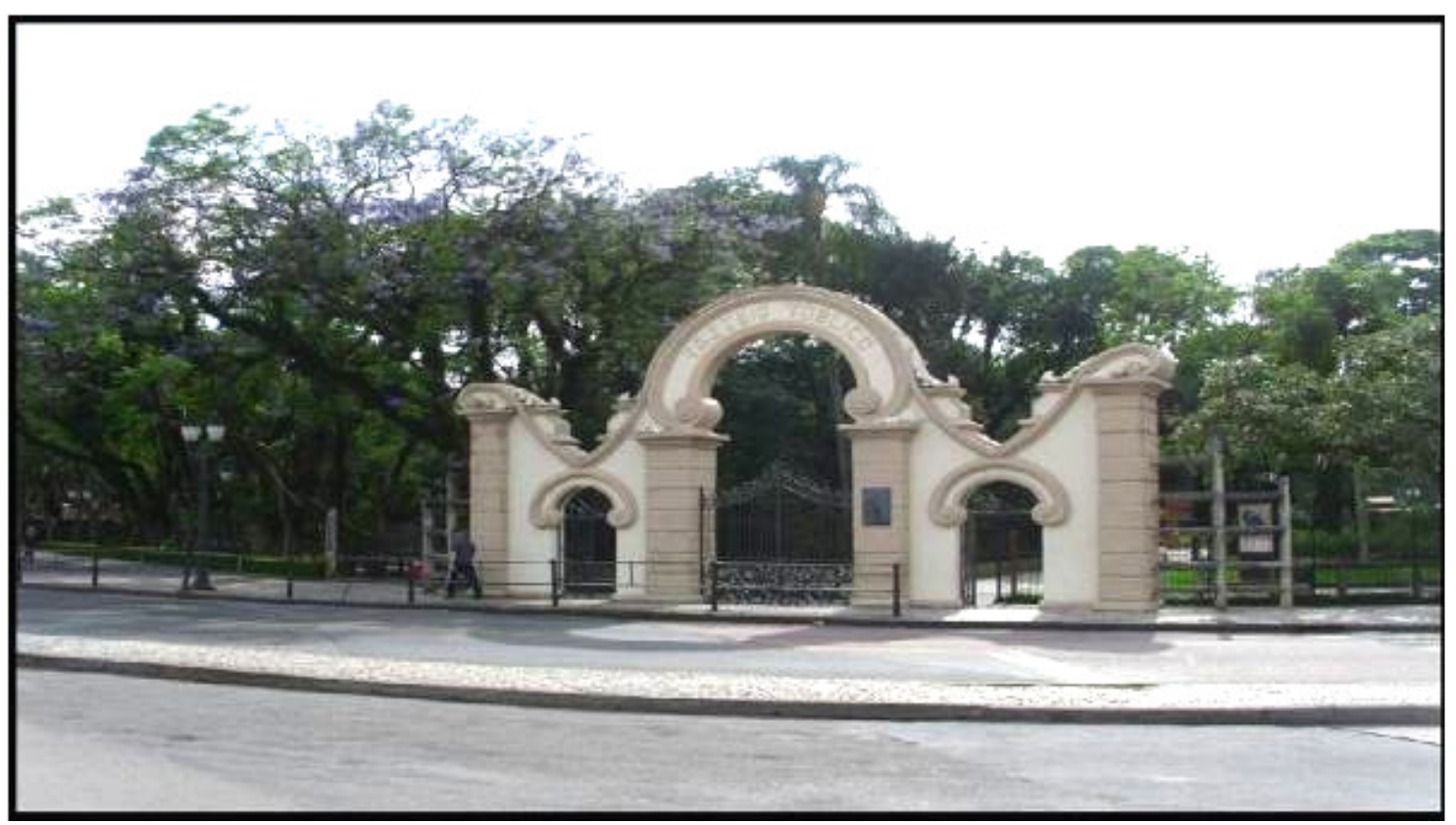

Figura 2. Portal do Passeio Público Fonte: a autora, 2011

Muitos fatos culturais também marcaram a história do Passeio. Uma réplica de um balão que ali alçou voo e caiu no telhado da Catedral Metropolitana, em 1909, hoje faz a alegria das crianças no playground. Emiliano Perneta, poeta simbolista, foi coroado no local, em 1911, como o "Príncipe dos Poetas Paranaenses" (SECRETARIA MUNICIPAL DO MEIO AMBIENTE DE CURITIBA, 2010). Atualmente, o Passeio funciona como sede administrativa do Zoológico Municipal de Curitiba, além de abrigar pequenos animais (FIG. 3). Também possui outras atrações como o terrário, que abriga diversas espécies de serpentes e lagartos e o Aquário, que possui variedades de peixe da região amazônica e da África. O verde de diversas espécies nativas e exóticas também encanta quem passa por lá. Carvalhos e ciprestes centenários, paineiras e jacarandás abrigam sob sua copa sabiás, canários-da-terra, tico-ticos, coleirinhas, pombos, pica-paus e as belas garças brancas (SECRETARIA MUNICIPAL DO MEIO AMBIENTE DE CURITIBA, 2010). 


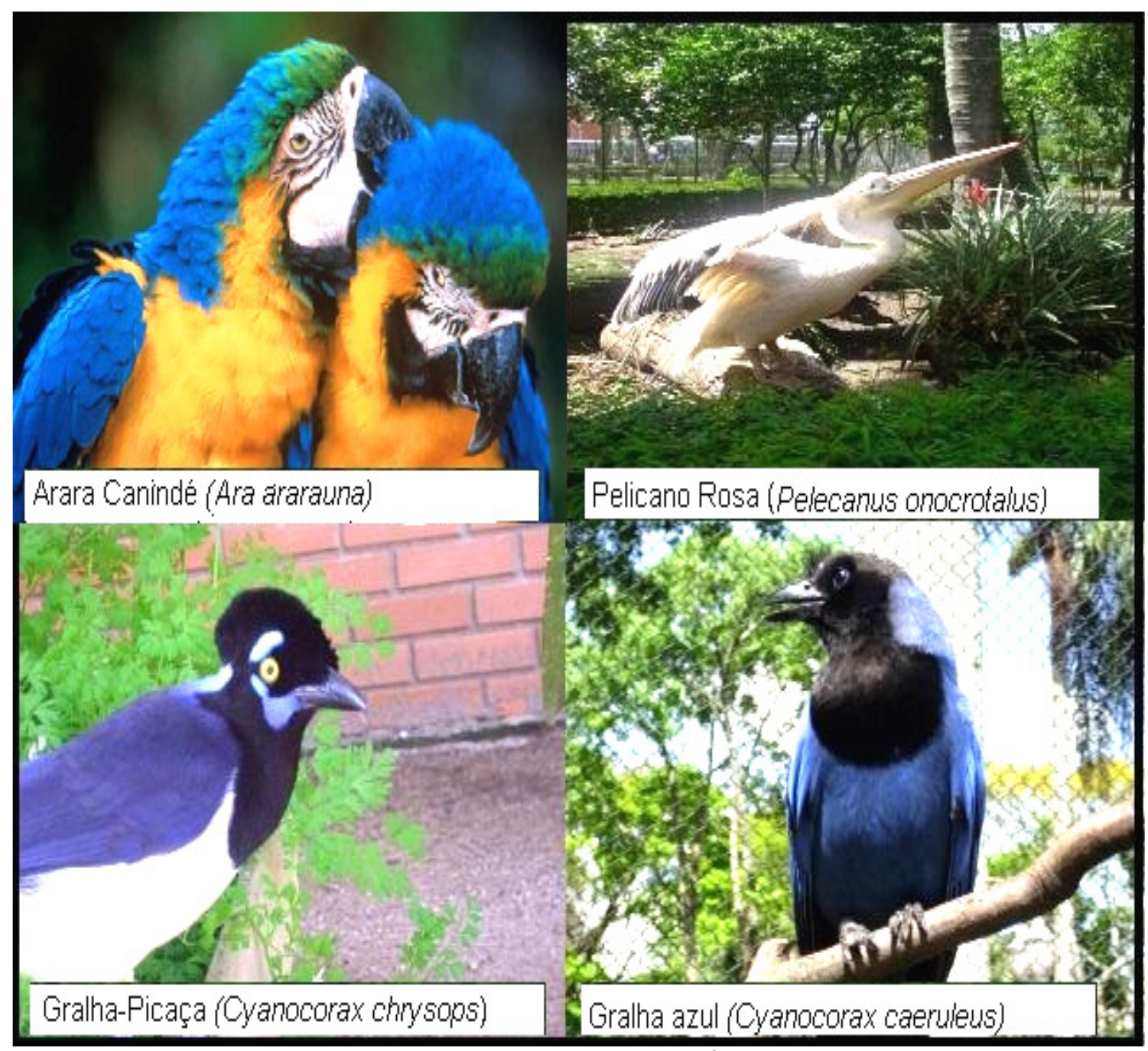

Figura 3. Aves do Passeio Público

Fonte: a autora, 2011

\section{RESULTADOS E DISCUSSÃO}

\subsection{Análise da infraestrutura básica do passeio público}

Para Ruschmann (2000), a infraestrutura básica é uma pré-condição para o desenvolvimento turístico. Itens como acessos, saneamento, energia, vias de circulação, segurança e sinalização são imprescindíveis para que se possa desenvolver a atividade turística em sua plenitude.

O Passeio Público se localiza num local privilegiado, o acesso é gratuito e o parque funciona de terça-feira a domingo, das 06 às 20 horas. O local abriga ainda a Sede Administrativa do Departamento de Pesquisa e Conservação da Fauna (zoológico), um centro veterinário, um posto policial, sanitários, bebedouros e alguns telefones públicos. A Prefeitura Municipal de Curitiba 
Monografias Ambientais

terceiriza os serviços de saneamento e energia. A manutenção dos jardins é realizada pelo Departamento de Parques e Praças.

Há um grande número de linhas de ônibus que passam próximas ao local, assim como é possível também chegar até lá a pé ou de bicicleta, já que a rota da ciclovia da cidade percorre a área externa do Passeio. Um dos fatores limitantes do uso turístico é a ausência de uma área destinada ao estacionamento de carros para visitantes.

Quanto à circulação interna, o Passeio Público apresenta pontos positivos e negativos. Apesar de todo o local apresentar espaços amplos e agradáveis aos visitantes, apenas uma parte da pavimentação é asfaltada, enquanto outra parte é constituída de terra e brita, o que dificulta o acesso de deficientes físicos a todas as dependências do local. Outro obstáculo ao deficiente físico é a ausência de rampas de acesso ao terrário, ao aquário e aos sanitários. O local, conta com apenas um sanitário masculino e um feminino em todo o perímetro do parque, o acesso é feito apenas por escadas.

Segundo a lei brasileira $n^{\circ} 7.853$, de 24 de outubro de 1989, o governo tem que tratar a pessoa com deficiência com prioridade, garantindo a acessibilidade. Nos termos do artigo 20 da Lei, cabe ao Poder Público e seus órgãos, assegurar às pessoas portadoras de deficiência o pleno exercício de seus direitos básicos, inclusive dos direitos ao lazer (BRASIL, 1989).

Em relação à sinalização, observa-se a presença de placas de identificação dos principais serviços e/ou atrativos. Há também, nas entradas do passeio, um mapa do local e seus atrativos, todos em bom estado de conservação. Para Silva (2011), a atividade turística requer uma leitura direta, permitindo clareza e simplicidade; sendo assim, lugares turísticos bem mapeados e sinalizados contribuem para uma comunicação facilitadora do que se espera e onde se espera encontrar na visitação, funcionando como elementos estratégicos para o desenvolvimento da atividade.

Nota-se, porém, a necessidade do uso de um segundo idioma, como o inglês, tanto na sinalização dos atrativos como nas placas de identificação dos animais, para que o turista estrangeiro também possa desfrutar do passeio e aprender assim como respeitar a fauna e flora do nosso país.

\subsection{Análise da infraestrutura turística do passeio público}

Este item se refere a tudo que está relacionado às áreas de alimentação, comércio turístico, áreas de entretenimento, informação turística e locais de descanso (RUSCHMANN, 2000).

O Passeio Público não possui posto de informações turísticas e também não oferece material de caráter informativo do local, embora o mesmo faça parte do roteiro turístico comercializado da cidade. "As informações representam o conteúdo do processo de comunicação entre o destino e o turista, sendo consideradas importantes e críticas para a retenção dos turistas em determinado destino" (GOHR; SANTOS; VEIGA, 2009, p. 173).

$\mathrm{Na}$ área de alimentação, o Passeio Público conta com uma pequena lanchonete, alguns quiosques espalhados pelo parque e um restaurante com capacidade para aproximadamente cem 
Monografias Ambientais

REMOANFSM

pessoas. Apesar de não apresentar grande variedade de opções de produtos, sua aparência visual não agride o ambiente e há uma comercialização controlada de produtos, o que é considerado importante no intuito de minimizar os impactos, principalmente na fauna do local, já que ainda existem muitos turistas não conscientes da interferência nos hábitos dos animais silvestres. Inclusive, a presença de placas orientando os visitantes a não alimentar o animal precisa ser reforçada.

Além da caminhada e a observação de animais, também há outras opções de entretenimento como o bicicletário, uma pista de patinação, pedalinhos, playground e academia de ginástica ao ar livre. Aos sábados, acontecem as feiras de hortifrúti e artesanato, das 07h às $13 \mathrm{~h}$.

Em relação aos locais de descanso, o Passeio Público possui bancos, em bom estado, em vários pontos, o que se considera importante para evitar a ocupação indiscriminada de áreas marginais à vegetação.

Em relação às placas de identificação de fauna e flora, o Passeio Público apresenta alguns problemas. Quanto ao estado das placas de identificação das árvores do local, todas se encontram em bom estado, contendo o nome popular e científico da planta (FIG. 4).

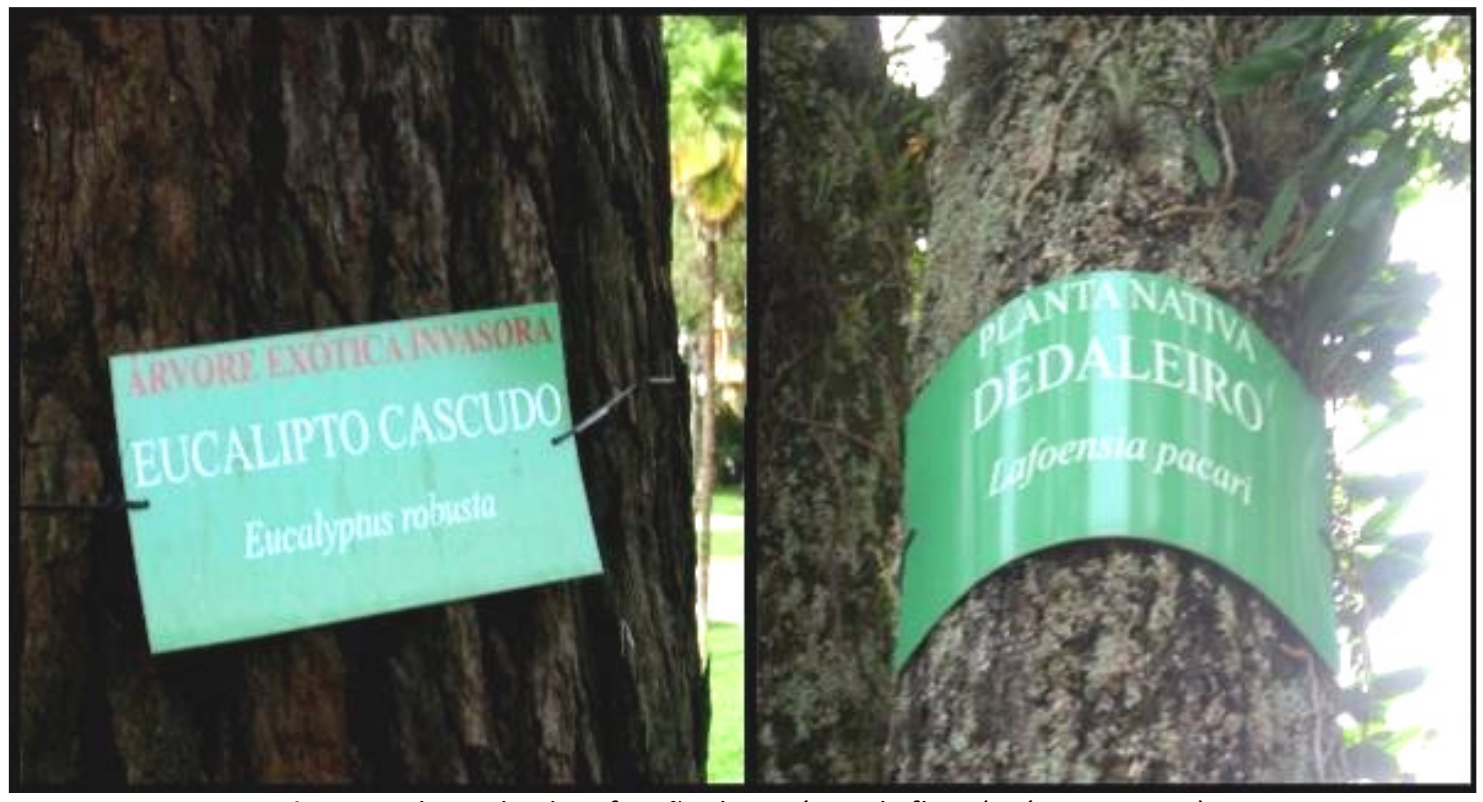

Figura 4. Placas de identificação de espécies da flora (exótica e nativa)

Fonte: a autora, 2011

O terrário contém dezoito recintos com diferentes espécies de serpentes, todos em bom estado e com identificação básica sobre o nome popular e científico do animal. Apenas uma delas contém uma placa mais elaborada, contando ainda com informações sobre a distribuição e alimentação do animal em questão.

Já as placas de identificação da fauna apresentam uma situação bem crítica. Dos cinquenta e quatro recintos de aves e pequenos animais, apenas vinte deles possuem placas de identificação da espécie em questão; algumas estão deterioradas e outras não possuem a identificação de todas 
Monografias Ambientais

as espécies do recinto, o que impede o visitante de obter um conhecimento básico sobre o animal (FIGs. 5 e 6).

As placas identificam o nome popular e científico do animal, alimentação e peso. No Aquário, foram encontradas também muitas placas deterioradas, além de alguns aquários vazios.

Para Jacobi (2003), as práticas sociais da sociedade contemporânea precisam ter como base o direito ao acesso à informação e educação ambiental, a fim de que seja possível minimizar ou até mesmo alterar o quadro de degradação ambiental.

Para Murta e Albano (2002, p.13), interpretar compreende "[...] o processo de acrescentar valor à experiência do visitante, por meio do fornecimento de informações e representações que realcem a história e as características culturais e ambientais de um lugar".

Deve-se ressaltar que a falta destes elementos, por se tratar de uma área de preservação, descaracteriza um pouco sua importância ambiental e o desempenho do turismo voltado à contemplação dos animais, que carrega intrinsecamente a oportunidade de disseminação da educação ambiental, estimulando novas percepções sobre as inter-relações sociais e naturais.

Murta e Albano (2002, p.14) destacam ainda que "[...] mais do que informar, interpretar é revelar significados, é provocar emoções, é estimular a curiosidade, é entreter e inspirar novas atitudes no visitante $[. . .]^{\prime \prime}$.

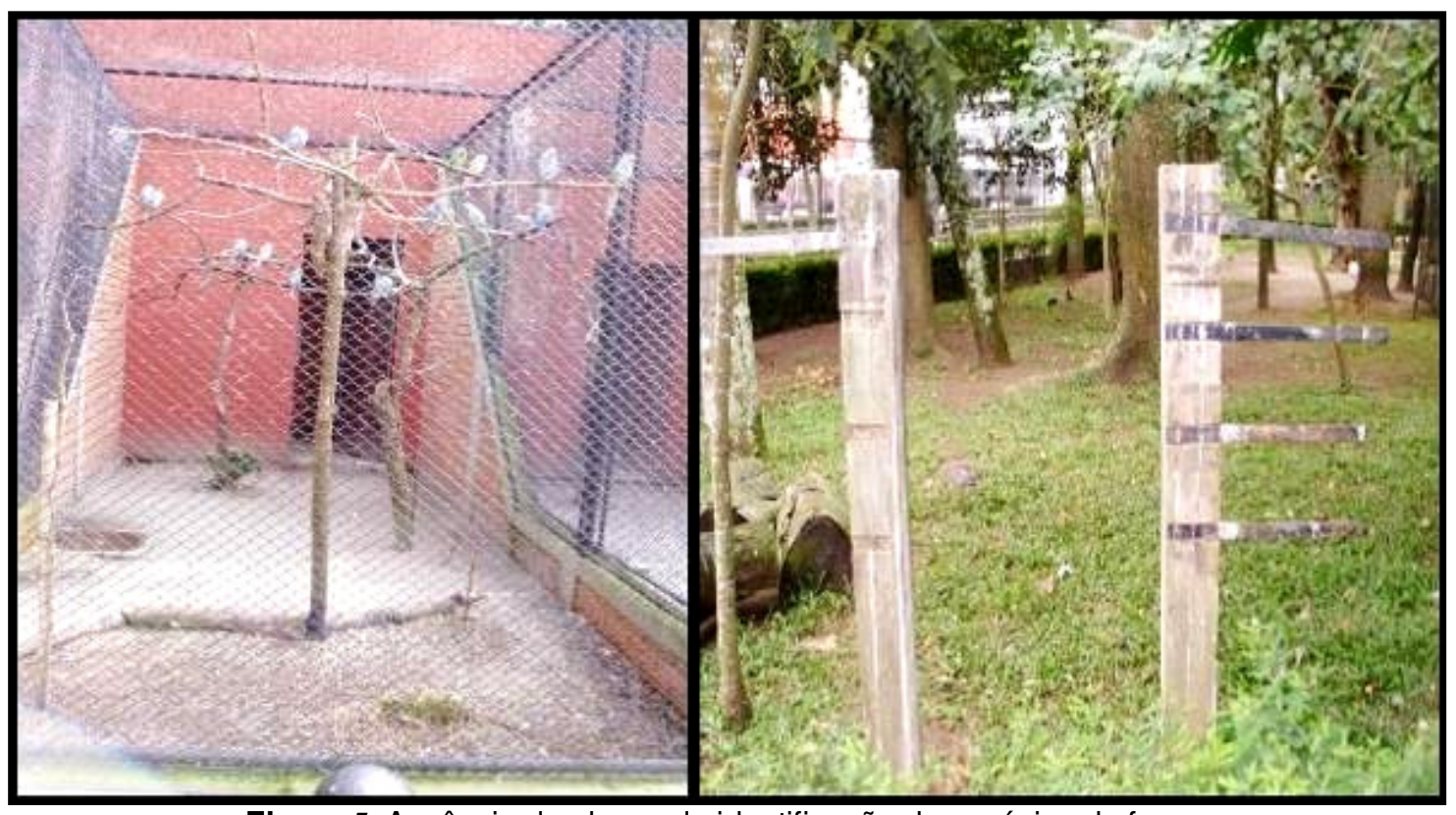

Figura 5. Ausência de placas de identificação de espécies da fauna

Fonte: a autora, 2011 
Monografias Ambientais

BOSA \& FÉXINA, v(7), no 7, p. 1608 - 1629, MAR-JUN, 2012.

(e-ISSN: 2236-1308)

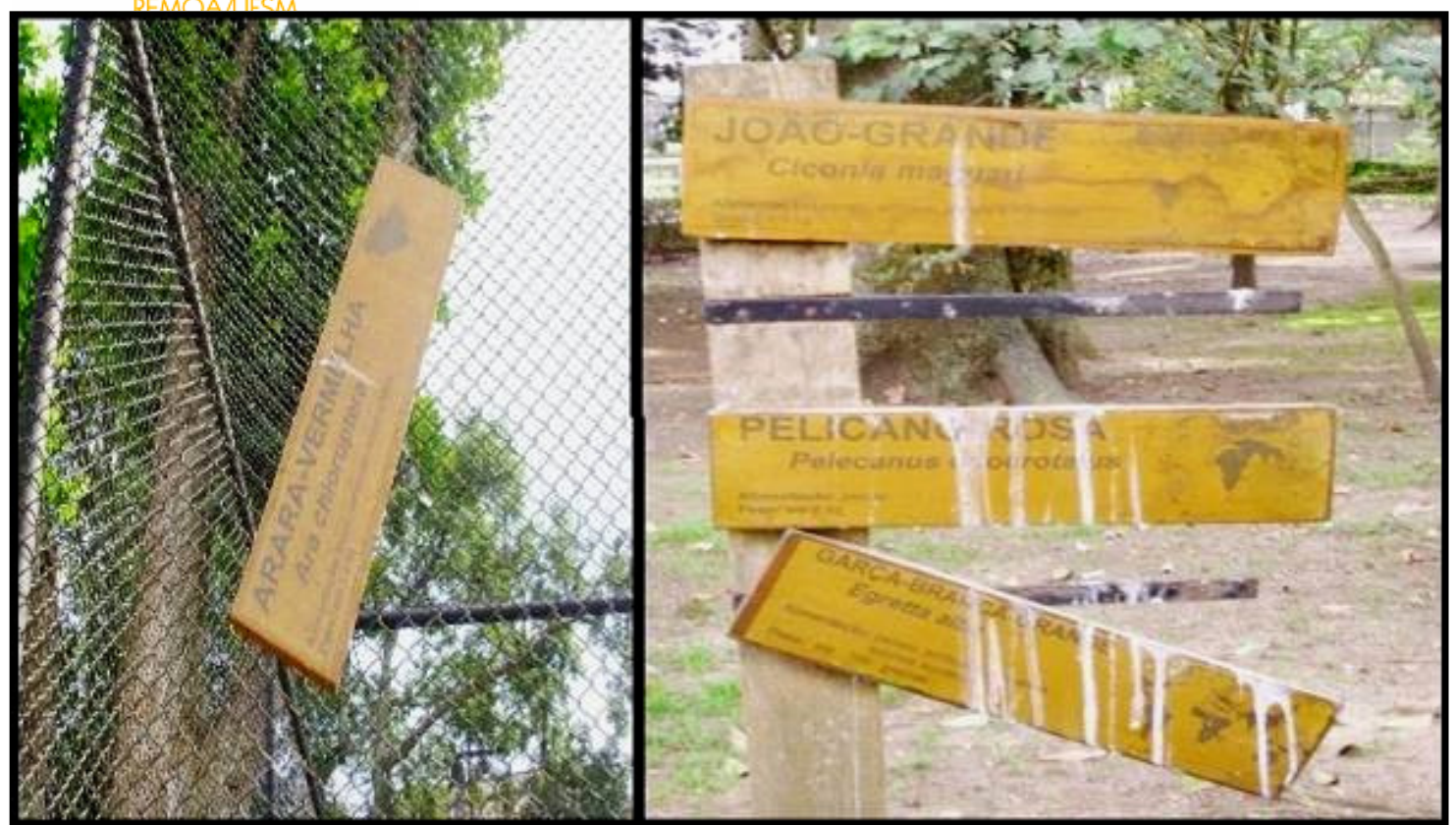

Figura 6. Placas de identificação de espécies deterioradas

Fonte: a autora, 2011

Em relação aos monumentos históricos, tanto o monumento do fundador Alfredo D’Escragnolle Taunay quanto a réplica do balão Granada se encontram em bom estado de conservação, mas o portal principal se encontra em estado regular, devido à umidade e crescimento de plantas na estrutura do mesmo (FIG. 7), havendo necessidade de manutenção periódica, principalmente por se tratar de um monumento tombado pelo Patrimônio Histórico e Artístico do Paraná, em $1974 . \quad$ Para Castanheira (2004, p. 83), "a manutenção do patrimônio histórico faz parte de um processo de conservação e recuperação da memória graças aos quais os povos mantém sua identidade".

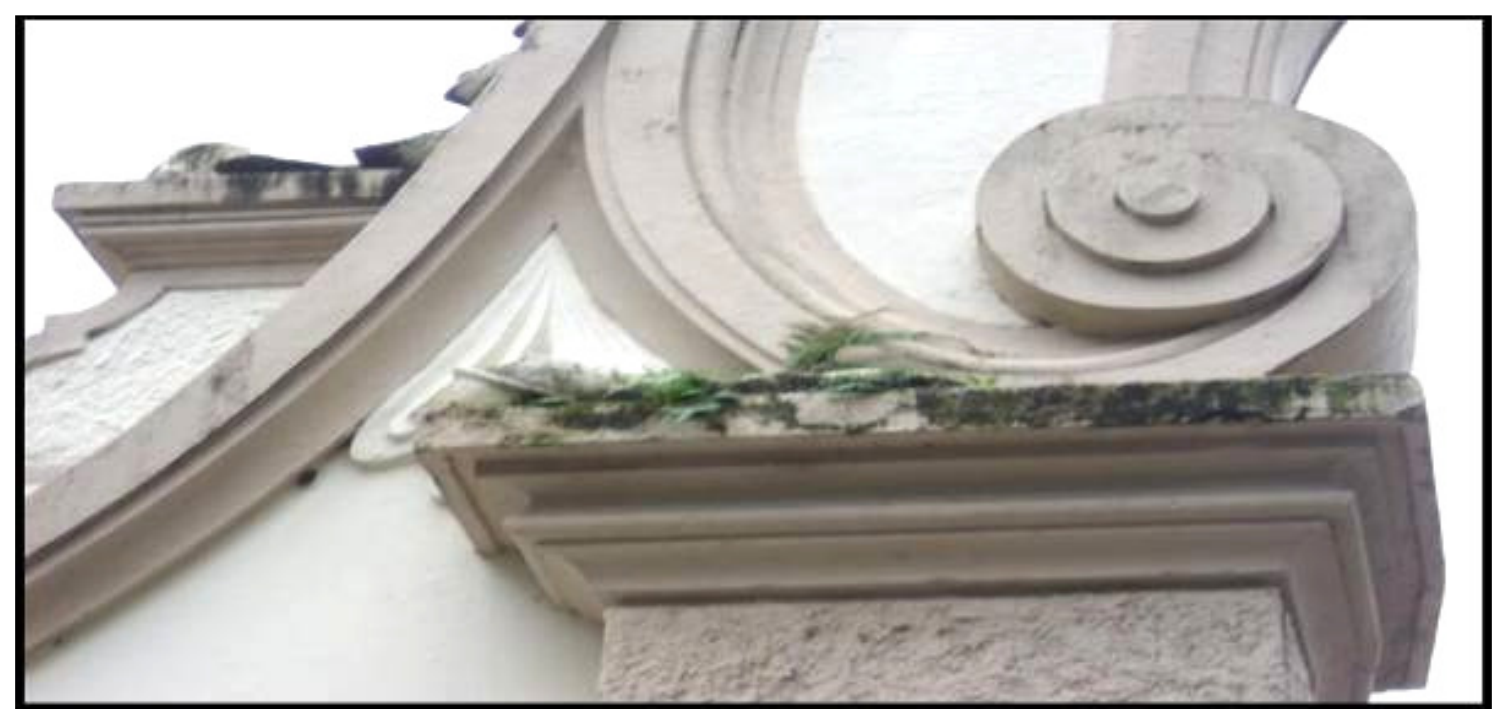

Figura 7. Crescimento de plantas no Portal do Passeio Público

Fonte: a autora, 2011 
Monografias Ambientais

BOSA \& FÉXINA, v(7), no 7, p. 1608 - 1629, MAR-JUN, 2012.

(e-ISSN: 2236-1308)

REMOANFSM

\subsubsection{Impactos negativos do turismo}

O turismo pode ser uma grande ferramenta para o desenvolvimento e conservação de um local, porém, se mal planejado, ele se transforma numa máquina de degradação ambiental e cultural. Para Ruschmann (2000), a relação entre turismo e meio ambiente é bastante complexa e o desafio está em conseguir equilibrar o desenvolvimento da atividade e a proteção ambiental.

Percebem-se alguns impactos negativos do turismo causados por excesso de visitação ou planejamento inadequado da estrutura física, como, por exemplo, quebra de estruturas frágeis nas dependências do parque, retirada de elementos da natureza como recordação e possível estresse dos animais, causados tanto pela visitação ruidosa como pelo intenso tráfego de veículos no entorno do local. A limpeza é realizada pela Prefeitura e, apesar de ser feita regularmente, pode-se encontrar muito lixo no chão, considerado o grande número de lixeiras espalhadas por todo o Passeio Público.

Outro problema registrado é a relação entre o visitante e os animais do recinto. Muitos visitantes dão alimentos aos animais, o que pode interferir seriamente seu estado de saúde. Além disso, alguns animais são muito mansos e vem ao encontro dos visitantes para serem tocados, o que também pode acarretar doenças e mudança de comportamento do animal (FIG. 8).

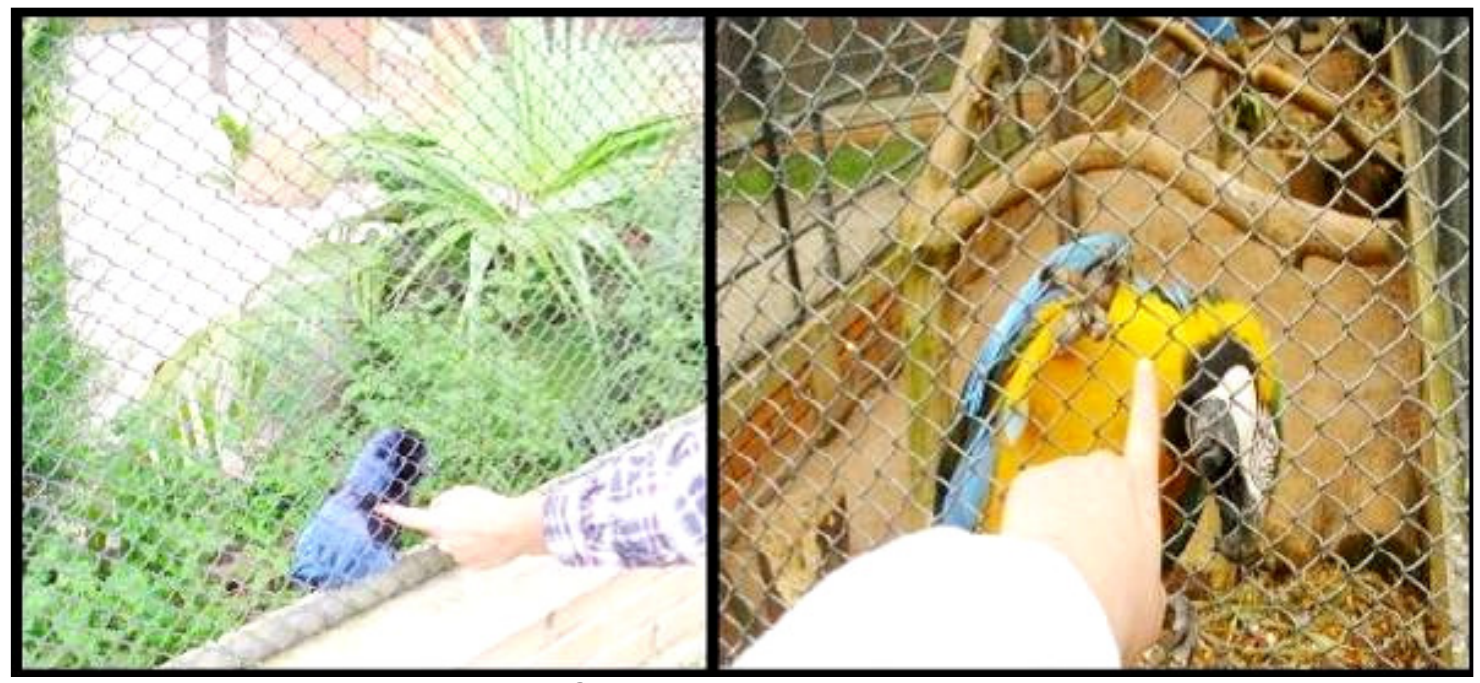

Figura 8. Contato entre animais e visitantes

Fonte: a autora, 2011

Também não há controle estatístico sobre o fluxo de visitantes que o Passeio Público recebe, o que poderia contribuir para estudos sobre os impactos na fauna e flora do local. Segundo Ruschmann (2000), o número máximo de visitantes que uma área pode suportar é importante para reconhecer que tanto os recursos naturais como os construídos pelo homem tem um limite para absorver visitantes, e que se ultrapassado, provoca sua deterioração.

Portanto, um bom planejamento é fundamental para que haja um equilíbrio entre os interesses ambientais e os interesses educacionais. 


\subsection{ANÁLISE DO QUESTIONÁRIO APLICADO AOS VISITANTES}

Os 100 visitantes que frequentavam o Passeio Público de Curitiba e responderam ao questionário no mês de agosto/2011 eram formados por 58\% de mulheres e $42 \%$ de homens (FIG. 9). A faixa etária dos visitantes era em sua maioria composta por pessoas de 18 a 30 anos (38\%), seguido pelas pessoas de 31 a 40 anos (35\%) e aqueles acima de 41 anos com 27\% (FIG. 10).

Este resultado demonstra que o local apresenta um público bem diversificado, sendo assim, a prática de educação ambiental pode alcançar homens e mulheres de todas as idades.

Deve-se ressaltar também a presença de muitas crianças e jovens escolares no Passeio Público durante todos os dias de visita.

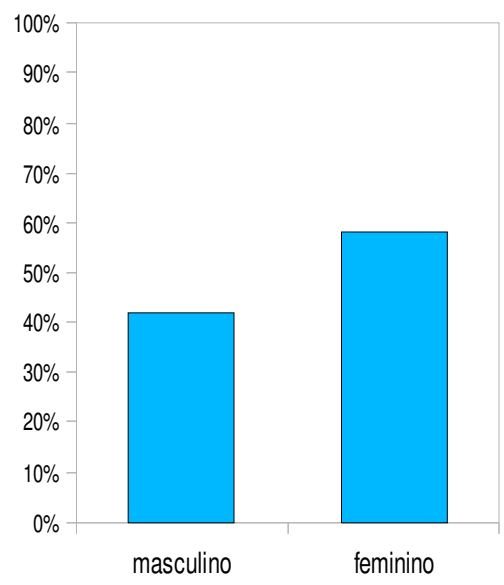

Figura 9. Sexo

Fonte: a autora, 2011

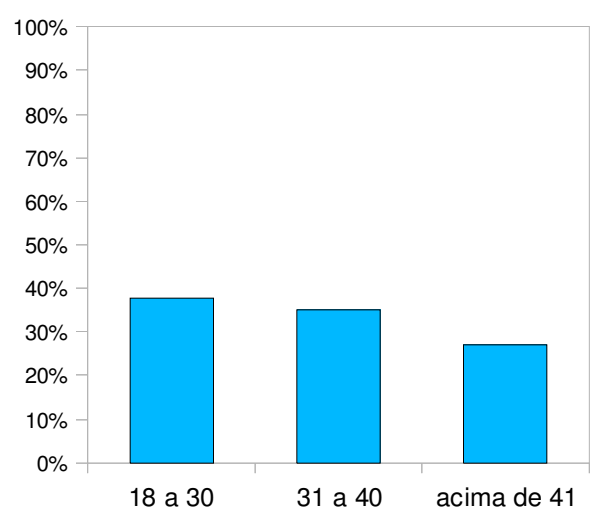

Figura 10. Faixa etária

Fonte: a autora, 2011

A maioria dos entrevistados possui ensino médio completo (38\%), seguido daqueles que possui o nível superior incompleto (20\%), e os que possuem nível superior completo, com $17 \%$ (FIG. 11), o que indica que os sujeitos da pesquisa possuem educação e estão minimamente 
Monografias Ambientais

conscientes sobre as questões ambientais atuais, o que facilita a utilização de ferramentas educativas. A visita aos animais foi o motivo mais requisitado pelo qual as pessoas visitam o local, com $42 \%$, seguido do lazer com $33 \%$ e prática de esportes com $27 \%$ (FIG. 12).

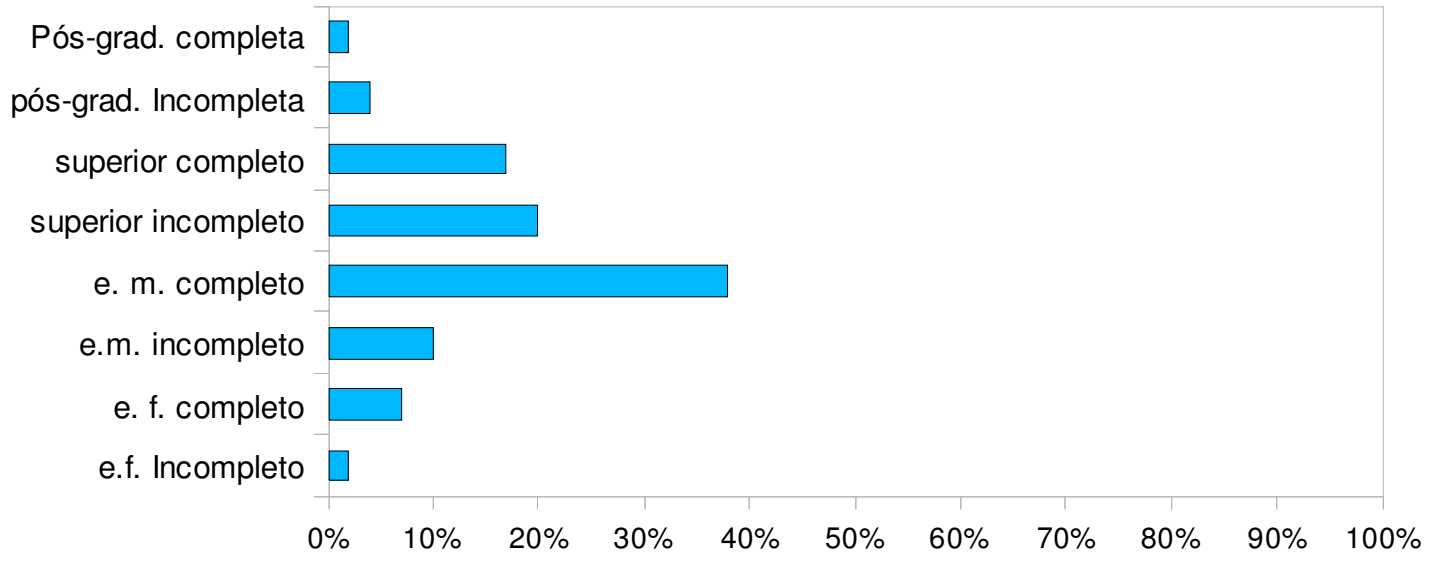

Figura 11. Escolaridade

Fonte: a autora, 2011

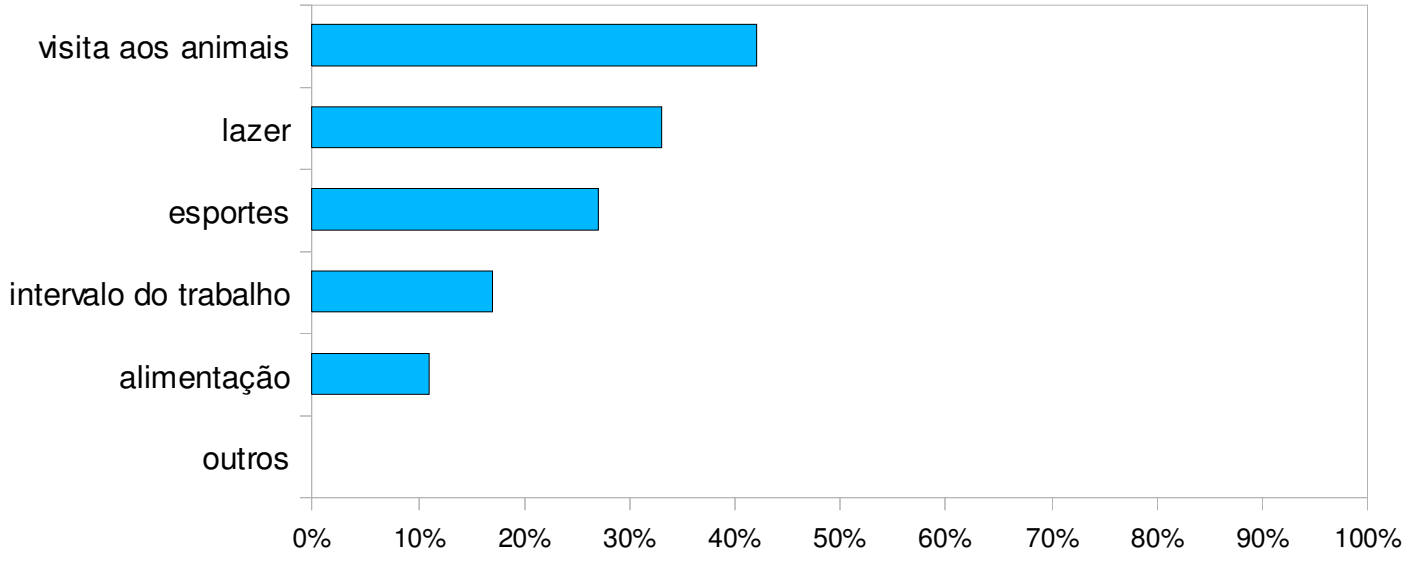

Figura 12. Qual foi o motivo da visita?

Fonte: a autora, 2011

Em relação à infraestrutura do Passeio Público, 46\% consideram-na regular (FIG. 13), sendo assinalados como os itens mais críticos do local os frequentadores do parque, com $54 \%$, seguidos da falta de segurança, citada por $44 \%$ dos entrevistados (FIG. 14). Este fato evidencia a insegurança do visitante em passear pelo parque e a necessidade de ações que mudem a imagem do Passeio Público, a fim de melhorar o relacionamento dos visitantes com o local.

A prostituição e o consumo/tráfico de drogas no Passeio Público trazem total insegurança ao local, afastando muitos curitibanos que se sentem desrespeitados quanto aos seus direitos.

De acordo com Ribeiro e Mattos (2005), áreas como a do Passeio Público, caracterizadas pela co-existência de múltiplos usos, como por exemplo, a localização central, o intenso fluxo de pessoas, as muitas atividades de lazer e serviços, assim como um significativo número de hotéis de 
alta rotatividade, são propícias ao desenvolvimento da prostituição e do consumo/tráfico de drogas. Além disso, quando esses grupos invadem tais áreas e formalizam seu território, eles acabam por exercer o poder no local e até controlar o acesso de outros grupos de indivíduos.

Embora a prostituição em si não seja considerada crime no Código Penal brasileiro, cabe a polícia enfrentar esta questão com ações que previnam ou coíbam tais atividades, uma vez que afetam a ordem e segurança pública. Por outro lado, pessoas ou estabelecimentos que facilitam ou induzem a prostituição e o consumo/tráfico de drogas são considerados criminosos. Neste caso, os hotéis ao redor do Passeio Público, conhecidos por lucrarem com esse tipo de atividade, são um dos principais facilitadores desse problema que envolve várias questões.

Constatou-se, através dos estudos de Ribeiro e Mattos (2005), que reformas urbanas e a implantação de outras ações em locais caracterizados por este tipo de problema, diminuem ou até mesmo fazem essas atividades desaparecerem.

Portanto, a implementação de um programa de educação ambiental no Passeio Público pode fazer com que outros grupos comecem a invadir o local, e assim, controlar o território novamente.

Mas para que o resultado dessa iniciativa seja positivo, é preciso que um conjunto de ações sejam tomadas simultaneamente às práticas de educação ambiental, como por exemplo, a atuação da polícia civil, a intervenção de políticos e do poder municipal.

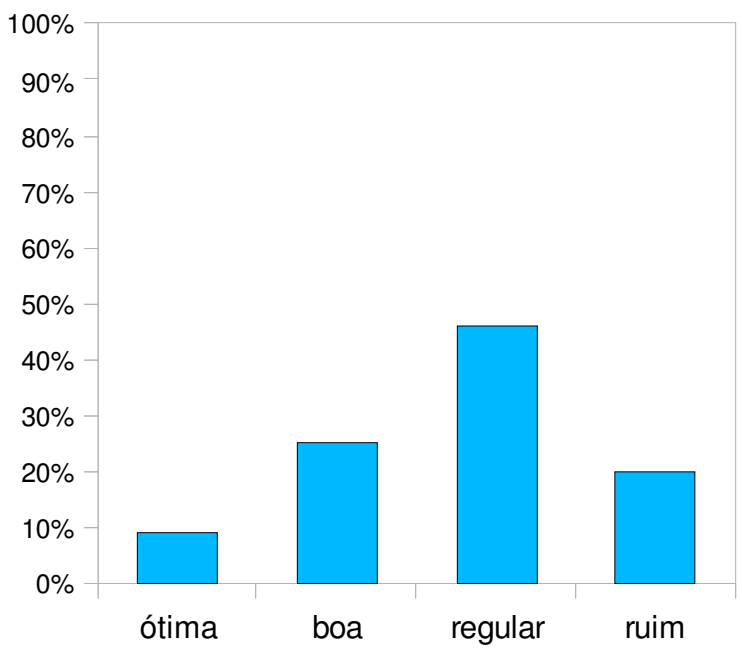

Figura 13. Qual sua opinião sobre a infraestrutura do parque?

Fonte: a autora, 2011 


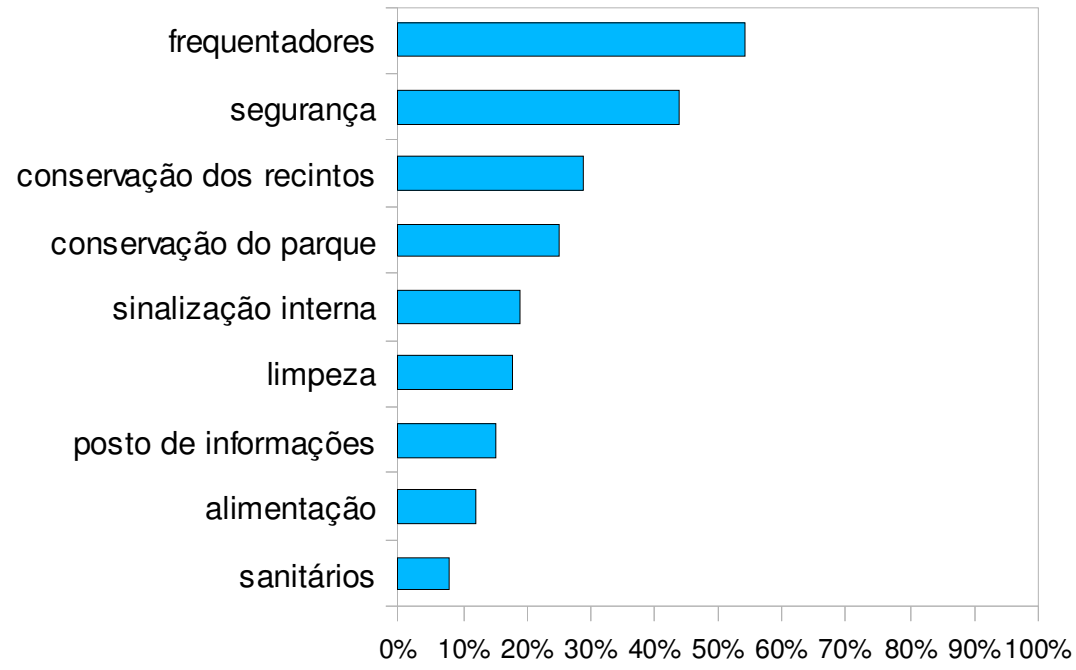

Figura 14. Quais os itens mais críticos do local?

Fonte: a autora, 2011

Dos entrevistados, 93\% dizem se incomodar com a destruição do meio ambiente (FIG. 15), e $61 \%$ deles acham muito importante utilizar o espaço do Passeio Público para disseminar ideias sobre educação ambiental (FIG. 16). O resultado indica que as pessoas estão abertas para aprender mais sobre o meio ambiente. Para Castanheira (2004), a educação é o meio mais eficiente de mudar as pessoas, pois faz com que o ser humano mude pelo conhecimento e não pela obrigação de seguir determinações ou legislações reguladoras.

não acha importante

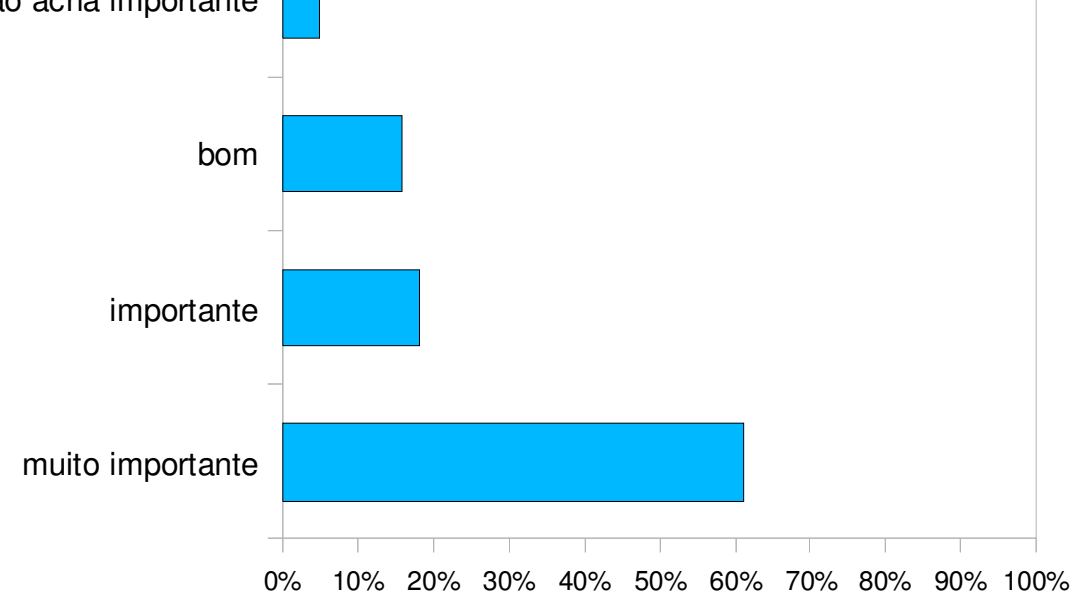

Figura 16. Qual sua opinião sobre utilizar o Passeio Público para ensinar sobre o meio ambiente?

Fonte: a autora, 2011 
Monografias Ambientais

REMOANFSM

Entre os tipos de informações que os visitantes mais gostariam de ver nas placas de identificação dos recintos, destacam-se curiosidades sobre os animais, com 57\%, hábitos e comportamentos dos animais com 55\%, ameaças à vida do animal com $34 \%$ e perigo de extinção com $32 \%$ (FIG. 17). Isto demonstra que as pessoas não se satisfazem apenas com o nome científico e popular das espécies. Elas querem saber como esses animais vivem, como se comportam e quais as curiosidades que envolvem determinada espécie.

Em se tratando de assuntos que o Passeio Público poderia oferecer, os resultados foram bastante diversificados. Dos entrevistados, $47 \%$ se interessam por ervas medicinais, seguido de animais com $45 \%$, tráfico de animais com $42 \%$, rios com $41 \%$, reciclagem do lixo com $39 \%$ e flores e plantas com $37 \%$ (FIG. 18).

Esta diversidade de opções demonstra que existem muitas possibilidades para o planejamento e realização de atividades de educação ambiental que despertem o interesse pelo assunto e pelo local.

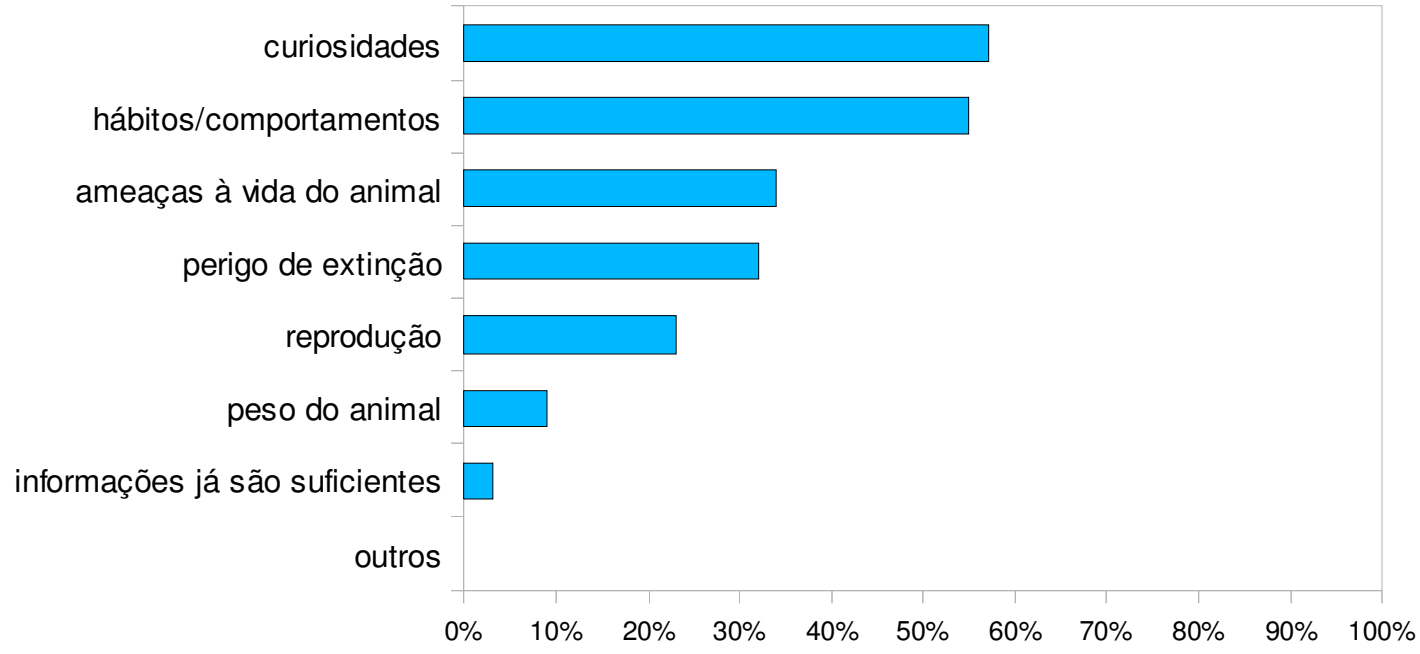

Figura 17: Que tipos de informações você gostaria de ver nas placas de identificação das espécies? (* resposta múltipla)

Fonte: a autora, 2011 


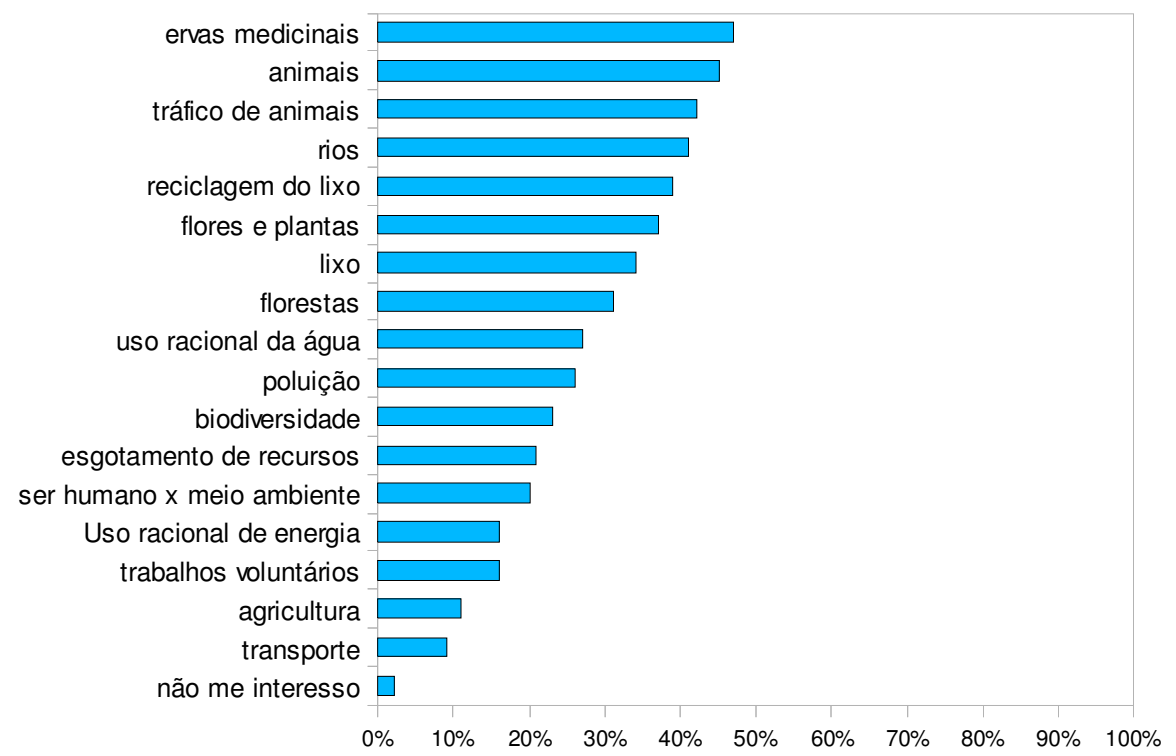

Figura 18. Que assuntos você se interessaria se estivessem sendo abordados no Passeio Público (* resposta múltipla)

Fonte: a autora, 2011

Os meios escolhidos para educação ambiental que chamam mais atenção são as maquetes, citado por $42 \%$ dos entrevistados, seguido de exposições com $39 \%$ e eventos com $28 \%$. Palestras e guias foram os itens menos votados, com 15\% e 16\%, respectivamente (FIG. 19). O resultado mostra que as pessoas buscam praticidade e elementos que estejam a sua disposição. Dos entrevistados, 96\% acreditam que suas atitudes podem melhorar se receberem mais informações sobre o meio ambiente (FIG. 20). Isto demonstra que o uso da criatividade, novidades e interação com o meio ambiente motiva as pessoas a serem mais positivas em relação ao seu próprio comportamento frente ao meio ambiente.

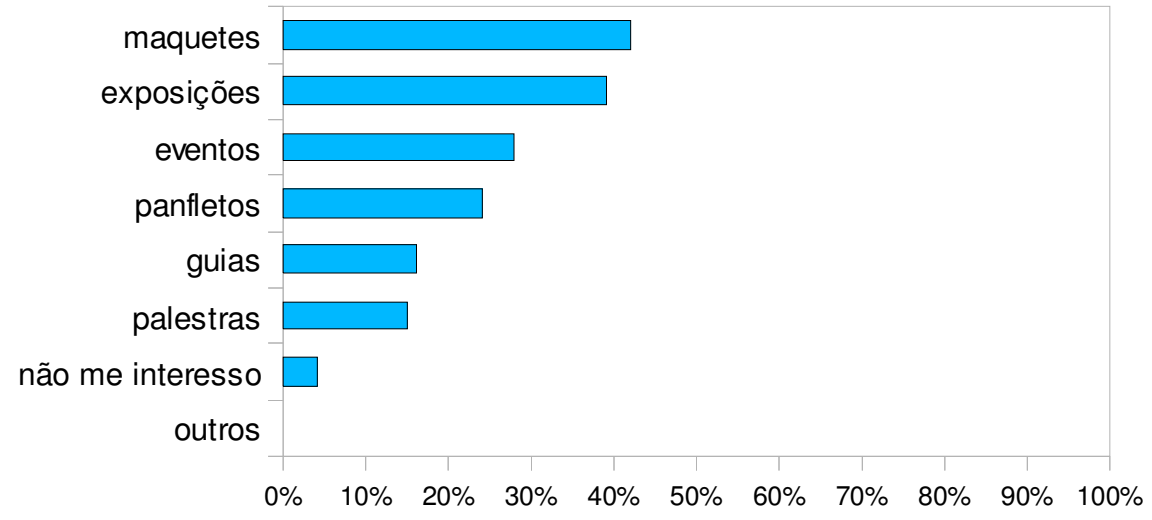

Figura 19. Através de que meios gostaria que os assuntos fossem abordados? ( ${ }^{*}$ resposta múltipla)

Fonte: a autora, 2011 


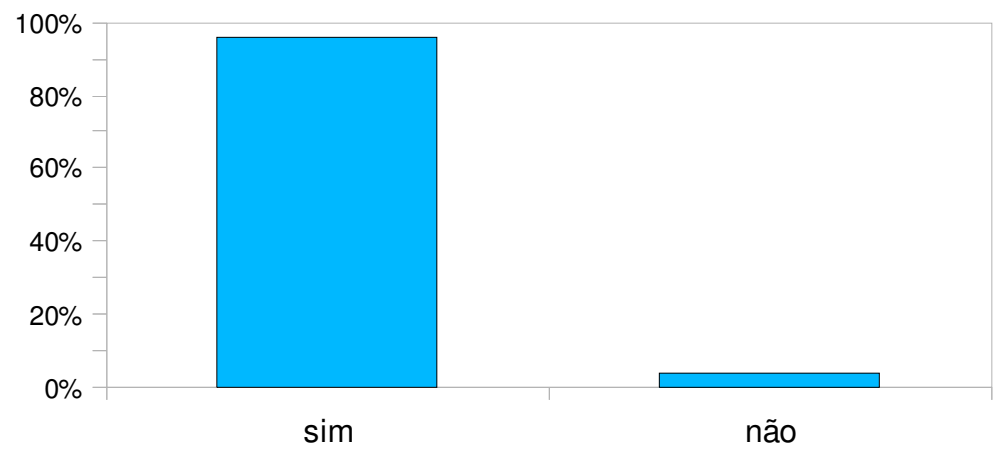

Figura 1. Você acha que seu comportamento pode mudar se conhecer mais sobre o meio ambiente?

Fonte: a autora, 2011

Segundo Jacobi (2003), o aumento da conscientização ambiental pode fazer com que as pessoas comecem a tomar decisões para controlar, minimizar ou alterar a degradação ambiental, além de questionar os poderes públicos quanto à falta de políticas e ações ligadas à sustentabilidade. Para Sauvé (2005), a educação ambiental estimula o surgimento de uma vontade de agir em cada uma das pessoas, contribuindo para o desenvolvimento de uma sociedade responsável.

\section{CONCLUSÃO}

O turismo e a educação, quando bem planejados, se relacionam e enriquecem um ao outro. A educação, através do turismo, é capaz de fortalecer seu conteúdo transmitido e o turismo, através da educação, pode sensibilizar inúmeras pessoas quanto à importância e os desafios da questão ambiental. O local estudado apresenta significativos recursos capazes de estimular a observação, reflexão e desenvolvimento do senso crítico, fazendo com que as pessoas repensem sobre os seus próprios modos de vida e a responsabilidade de cada um no futuro do planeta.

Diante dos resultados, fica evidente o interesse dos visitantes em obter mais conhecimento sobre a questão ambiental, já que muitos que vão até o local vão em busca de algo mais, ou seja, o contato com a natureza. Da mesma forma, também fica evidente que a necessidade de maior esforço e investimento dos órgãos públicos em cumprir seu papel de educar o cidadão é o maior problema: é preciso que as pessoas tenham acesso ao conhecimento, uma vez que este é apenas uma das ferramentas para a construção de uma sociedade sustentável. A falta de sinalização despertando o visitante para a importância da fauna descaracteriza os ideais preservacionistas do local e não incentiva experiências transformadoras de educação, capazes de induzir mudanças de atitude a favor do meio ambiente.

Deve-se ressaltar a necessidade de estudos futuros que busquem a melhor metodologia e temas a serem aplicados na prática de educação ambiental no Passeio Público, assim como o planejamento e estudos precisos para minimizar os impactos que tais ações causariam na fauna e 
flora local, a fim de que o objetivo de transformação social seja atingido sem prejudicar o seu meio.

Para a implantação da educação ambiental, que estimulem a aproximação e valorização do local pelos cidadãos, além dos objetivos educativos, sugere-se:

- criar um programa para sensibilização e mobilização de funcionários quanto à utilização do parque como instrumento de educação ambiental

- reforçar trabalhos da polícia que coíbam as atividades de prostituição e consumo/tráfico de drogas no local, além da presença da polícia feminina para fazer revistas nos banheiros das mulheres

- investigar os hotéis que são favorecidos e lucram com as atividades de prostituição e consumo de drogas, já que isso é considerado ilegal

- exigir que autoridades tomem providências para fechar estabelecimentos ilegais

- aumentar o número de informações nas placas de identificação de fauna e flora, para que o visitante possa aprender e conhecer mais sobre as espécies do recinto, principalmente informações que façam as pessoas pensarem sobre suas atitudes frente à preservação. Pode-se citar como exemplo, a divulgação de como o animal que as pessoas compram através do tráfico pode interferir na conservação da biodiversidade

- implementar maquetes em alguns pontos estratégicos do parque, que expliquem como funciona a relação entre o homem e o ambiente em sua totalidade, onde o homem é o protagonista da degradação ambiental. Por exemplo: criação de duas maquetes que expliquem o ciclo da água, sendo que uma delas explica o conteúdo sem a intervenção do homem, enquanto a outra mostra a interferência do homem neste processo e as possíveis consequências no meio ambiente. Outros assuntos que podem ser abordados incluem solo, lixo, árvores e animais, reforçando a relação de causa e consequência

- reservar espaços para divulgação de trabalhos escolares com temática ambiental, em painéis espalhados pelo parque, feito através de parceria com escolas locais, onde cada escola será responsável, ocasionalmente, a trabalhar o tema com seus alunos. Além de reforçar a educação ambiental formal, os alunos poderão acrescentar valor à esta experiência, visitando a exposição da própria escola assim como de outras escolas da cidade.

- criar um espaço destinado à plantação de ervas medicinais à população, já que este foi o motivo de maior interesse dos entrevistados. Além de resgatar a importância do uso das plantas e valorizar o conhecimento tradicional, que desde a antiguidade são utilizadas para a cura e alívio dos males, agrega outros fatores como o incentivo ao cultivo e consumo de alimentos orgânicos, acesso à saúde com baixo custo e eficácia. O responsável pela distribuição das ervas deve receber um treinamento profissional para indicar tratamentos e formulas das mesmas

- incluir placas com identificação das espécies de pássaros que podem ser observadas ao ar livre no parque. Exemplo: informações e curiosidades sobre a garça branca, socós e bem-te-vis

- criar um espaço (painel em ponto estratégico) destinado à divulgação de trabalhos voluntários e dicas de como as pessoas podem contribuir para a preservação. Pode-se citar como exemplo: instruções para o plantio de mudas, como denunciar o tráfico, como economizar água e energia - instituir parcerias com empresas para financiar publicações periódicas sobre o meio ambiente e sobre iniciativas que estão dando certo em escolas e comunidades 
Monografias Ambientais

BOSA \& FÉXINA, v(7), no 7, p. 1608 - 1629, MAR-JUN, 2012.

(e-ISSN: 2236-1308)

REMOANFSM

- fazer contato com empresas produtoras de mudas, para doação de mudas de arvores nativas, a fim de que o Passeio Público possa realizar, ocasionalmente, a distribuição das mesmas para a comunidade carente que frequenta o local, demonstrando a importância de se plantar uma árvore - contratar estagiários para receber grupos escolares para visita e atividades de conscientização - elaborar um mapa com endereços de "ecopontos" em Curitiba, como por exemplo, locais onde é possível a população entregar seu óleo usado, para ajudar o meio ambiente

\section{AGRADECIMENTOS}

Os agradecimentos são dirigidos aos funcionários do Passeio Público, que disponibilizaram as informações necessárias para o desenvolvimento deste projeto.

\section{REFERÊNCIAS}

BERTE, R. Educação ambiental: construindo valores de cidadania. Curitiba: Champanhota, 2004.

BONFIM, M.V.S. Por uma pedagogia diferenciada: uma reflexão acerca do turismo pedagógico como prática educativa. Turismo Visão e Ação, v.12, n.1, p.114-129, jan/abr. 2010.

BRAGA, D.C. Planejamento turístico: teoria e prática. Rio de Janeiro: Televier, 2007.

BRASIL. Lei no 7.853, de 24 de outubro de 1989. Dispõe sobre o apoio às pessoas portadoras de deficiência, sua integração social, sobre a Coordenadoria Nacional para Integração da Pessoa Portadora de Deficiência Corde, institui a tutela jurisdicional de interesses coletivos ou difusos dessas pessoas, disciplina a atuação do Ministério Público, define crimes, e dá outras providências. Diário Oficial da União: República Federativa do Brasil, Brasília, DF, 24 out. 1989. Disponível em: <http://www.planalto.gov.br/ccivil 03/leis/L7853.htm>. Acesso em: 25 set. 2011.

BRASIL. Lei no 9.795, de 27 de abril de 1999. Dispõe sobre a Educação Ambiental, institui a Política Nacional de Educação Ambiental e dá outras providências. Diário

Oficial da União: República Federativa do Brasil, Brasília, DF, 27 abril 1999. Disponível em: <https://www.planalto.gov.br/ccivil_03/leis//9795.htm>. Acesso em: 23 set. 2011.

CASTANHEIRA, D.B. A Educação ambiental como foco do turismo pedagógico. Ciência \& Conhecimento, v.1,n.4, p.79-92, nov. 2004.

GOHR, C. F.; SANTOS, L.C.; VEIGA, M.F. A informação como um elemento chave para a qualidade do produto turístico: uma análise dos postos de informações turísticas do município de Florianópolis- SC. Perspectivas em Ciência da Informação, v.14, n.2, p. 169-186, maio/ago. 2009. Disponível em:<http://www.scielo.br/pdf/pci/v14n2/v14n2a12.pdf>. Acesso em: 10 set. 2011. 
JACOBI, P. Educação ambiental, cidadania e sustentabilidade. Cadernos de Pesquisa, n.118, p. 189-205, março/2003. Disponível em: <http://www.scielo.br/pdf/cp/n118/16834.pdf>. Acesso em: 05 abr. 2011.

MARCONI, M.A.;LAKATOS, E.M. Técnicas de pesquisa: planejamento e execução de pesquisas, amostragens e técnicas de pesquisa, elaboração, análise e interpretação de dados. 7. ed. São Paulo: Atlas, 2009.

MARTINS, G.A.; LINTZ, A. Guia para elaboração de monografias e trabalhos de conclusão de curso. São Paulo: Atlas, 2000.

MINISTÉRIO DAS RELAÇÕES EXTERIORES. O Brasil no combate ao tráfico de animais silvestres. Brasília: Ministério das Relações Exteriores, 2004.

MURTA, S.M.; ALBANO, C. Interpretar o patrimônio: um exercício do olhar. Belo Horizonte:UFMG, 2002.

NOGUEIRA, D. Passeio público, o mais central. Disponível em: $<$ http://www.gazetadopovo.com.br/imobiliario/conteudo.phtml?tl=1\&id=1002792\&tit=Passeio-Publico-omais-central>. Acesso em: 05 nov. 2010.

RIBEIRO, M. A. C. ; MATTOS, R.B. Territórios da Prostituição nos Espaços Públicos da Área Central do Rio de Janeiro. Revista Brasileira de Geografia, Rio de Janeiro, v. 59, n. 1, p. 25-41, 2005.

RUSCHMANN, D.M. Turismo e planejamento sustentável: a proteção do meio ambiente.6.ed. Campinas: Papirus, 2000.

SAUVÉ, L. Educação ambiental: possibilidades e limitações. Educação e Pesquisa, v.31, n.2, p. 317-322, maio/ago 2005. Disponível em:

< http://www.scielo.br/pdf/ep/v31n2/a12v31n2.pdf >. Acesso em: 20 set. 2011.

SECRETARIA MUNICIPAL DO MEIO AMBIENTE DE CURITIBA. Parques e bosques: passeio público. Disponível em:

$<\quad$ http://www.curitiba.pr.gov.br/conteudo/parques-e-bosques-passeio-publico-secretaria-municipal-do-

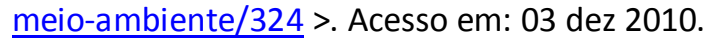

SILVA, O.F. Aportes para o desenvolvimento do turismo na Vila de Mazagão Velho - AP: mapeamento e sinalização como estratégias de comunicação. Estação Científica, v.1, n.1, p. 41-5, jan/fev. 2011. Disponível em:

< http://periodicos.unifap.br/index.php/estacao/article/download/184/172 >. Acesso em: 2 set. 2011. 